Ye.V.Terekhov, Cand. Sc. (Econ.), Assoc. Prof., orcid.org/0000-0002-4816-6072, Yu. I. Litvinov, orcid.org/0000-0002-1801-6719
National Mining University, Dnipro, Ukraine, e-mail: terehoff@t-online.de

\title{
ECO-ORIENTED MANAGEMENT OF MANUFACTURING AND SUPPLY ACTIVITY OF MANGANESE ORE RAW MATERIALS SUPPLIER
}

Purpose. Theoretical substantiation of the principles and recommendations development as for the development of manganese ore products of domestic mining companies' competitiveness on the basis of the application of the ecologically-oriented approach to management of their production and sales activities. Substantiation of the methodical approach to the estimation of the impact of the level of implementation of environmental protection programs of the mining enterprise on the formation of the technological cost of its products, which is the basis of its successful advancement in the market.

Methodology. The following methods were used in the course of the research: the method of theoretical generalization and systematization (for determining the peculiarities of the formation of competitiveness of domestic producers of manganese raw materials, depicting the main tendencies in the development of the manganese market, defining the directions of implementation of the ecologically-oriented management of production activities of the mining enterprise), the statistical method (for displaying indicators that characterize the production activity of enterprises producing manganese ore), the analytical method (for definition of the factors affecting the competitiveness of manganese ore from local producers).

Findings. A methodical approach to the formation of the competitiveness of the mining company products is proposed on the basis of the conducted research based on the introduction of ecologically-oriented management of its production activities, taking into account the environmental consequences of the development of the deposit and the costs associated with them, in determining sales volumes and components of pricing of manganese ore products.

Originality. A methodical approach to the formation of the mining company products competitiveness is proposed based on the introduction of the ecological-oriented system of its production and sales activities management, which implies significant impact of the level of environmental protection programs implementation of the enterprise and measures for more rational development of the ore deposit to reduce the technological cost of production as a key factor in the formation of demand for manganese ore raw materials at the domestic and foreign markets.

Practical value. The obtained results are aimed at improving the methodological bases of the mining company competitiveness management with the use of pricing methods for its formation. Consideration of the influence of environmental factors on the development of the mine on the competitiveness of manganese ore raw materials will allow defining purposefully its cost characteristics, favorable for increasing its demand in the market.

Keywords: manganese ore materials, eco-oriented management, production society, competitiveness, landscape, rational environment of entrails

Introduction. The modern manganese market is characterized by increasing competition from the global producing countries of this metal. The growth in demand for steel products leads to increase in demand for manganese raw materials as an indispensable chemical element in the steelmaking industry, but the development of new manganese deposits with high content of a useful component, the development of alternative technologies for its extraction, poses a threat to the market positions of those countries that are traditional suppliers of manganese, and, in particular, for domestic enterprises. Today, companies that specialize in manganese ore extraction in Ukraine are facing the problem of increasing competitiveness of their products in the global and domestic markets, which, in the conditions of a high level of technogenic loading of mining facilities on the natural environment and losses of useful components in the subsoil, should be achieved, first of all, through the adoption of managerial decisions, focused on the introduction of technologies for the more com-

(C) Terekhov Ye.V., Litvinov Yu. I., 2018 plete extracting of minerals from the depths and the slowdown of withdrawal rate of land areas by technological facilities of mining enterprises.

Thus, today there are relevant research studies related to the search for ways to increase the manganese raw materials of domestic production competitiveness on the basis of solving environmental problems of mining, affecting the cost price of commodity products of the manganese supply company. According to this, the ecologically-oriented management of the mining activity of the mining enterprise should be directed at the formation of a supply of manganese ore raw materials, the production of which is associated with a minimal scale of environmental degradation and more complete extraction of minerals from entrails.

Analysis of the recent research and publications. The question of substantiation of managerial decisions, concerning the planning of mining objects according to the criteria of ecological and economic efficiency, is reflected in numerous publications of domestic and foreign researchers. So, scientists Pivnyak G. G., Vagonova O. G., Prokopenko V. I. [1] emphasize the importance of taking 
into account the interests of both a mining company and landowners for the alienation of land for the development of minerals. The way to this is to make technological decisions on limiting negative mining impacts on land resources and to build an economic mechanism to compensate all possible negative changes in the qualitative state of mining grounds, which will reduce the conflict component of mining land use.

Mormul T. M. [2] developed criteria for assessing the land low-maintenance technological schemes of open field development, reflecting the level of land restoration in terms of quality and extension of their violations, as well as their cost estimation. On the basis of this, it is possible to choose the mode of development of mineral deposits, which is characterized by the least cost losses of the mining company in terms of compensation of land value that is subject to violations in the technological cycle of deposit development.

Sobko B. Y. [3] was concerned with the substantiation of the possibilities of reducing the costs of overturning operations in the open mining process in order to form a lower level of the cost of production of a mining company, in spite of the limited possibilities of improving its qualitative parameters.

Thus, the above mentioned researchers point out the necessity to find ways to reduce costs associated with the conduct of preparatory work in the mining company through the introduction of less capital-intensive schemes and costs associated with the non-compliance of environmental legislation with respect to land resources of the mining lease.

Researchers Friedel Hütz-Adams, Ann-Kathrin Voge and others [4] note that the gradual exhaustion of the metal deposits in the best condition will make additional investments in the development of worse fields, improving the system of minerals development and processing, the establishment of recycling schemes, which will lead to the increase in the cost price of metal products and deterioration of its market positions. Because of this, it is important to seek the reducing of losses of minerals in the subsoil with economically viable conditions, as the development of new deposits causes more extensive environmental interference and, consequently, more negative environmental and social consequences. To confirm this, Matyukha V. V., Sukhin O. M. [5] note that the complication of mining and geological conditions for the extraction of minerals, the availability of obsolete, imperfect mining technologies, and the considerable work of the main production facilities of mining enterprises lead to extremely high losses of minerals in the entrails during their extraction.

The paper [6] states that environmental costs can have a significant impact on the the planning content of the enterprise mining activity and therefore should be considered while determining the efficiency of production and marketing of its products. The authors propose methodical approaches to the planning of economic indicators of mining activity on the basis of taking into account its environmental costs at the same level with other internal costs of extraction and mineral beneficiation. So, it is possible to determine different variants of investment of funds in the activity of the mining enterprise according to the components of its ecological and economic efficiency.

While paying tribute to the achievements of other researchers, it should be noted that the issue of methodical support for the process of making managerial decisions on increasing the mining company production competitiveness in conditions of development of a manganese deposit on the basis of taking into account the need for a more effective solution of environmental issues affecting the cost price of manganese ore raw materials remains unresolved.

Unsolved aspects of the problem. The issue of increasing the efficiency of production and sales of mining products is reflected in numerous studies on the problems of functioning of the country mining industry. However, it should be noted that today insufficient attention is paid to the assessment of the economic effect of the use of technological schemes that allow for a more complete extraction of minerals from mineral resources and conservation of land resources due to its influence on the formation of the cost price and, accordingly, the competitiveness of the mining company, and, in particular, manganese ore raw materials. This is the actual and insufficiently researched aspect of the problem of increasing the ecological and economic efficiency of the activity of domestic enterprises of the mining industry.

Objectives of the article. The purpose of the article is theoretical substantiation of the principles and development of practical recommendations on the manganese ore products of domestic mining enterprises' competitiveness on the basis of the application of an ecologically-oriented approach to management of their production and sales activities. Accordingly, it is necessary to substantiate the methodical approach to assessing the impact of the level of implementation of environmental protection programs of the mining enterprise on the formation of the technological cost of its products, which is the basis of its successful advancement in the market.

Presentation of the main research. The development of the domestic economy in the long run depends to a large extent on the level of development and utilization of its mineral resource potential. Its own extraction of minerals should be a factor in ensuring the state raw material security in conditions of significant fluctuations of prices and volumes of mineral raw material supply at the world level, as well as increasing its export potential.

Ukraine, having large deposits of manganese ores in its entrails, the developed mining and processing complexes, is among the leading countries in the mining and enrichment of this mineral [5]. Domestic reserves of manganese allow covering domestic needs of the country for 450 years in advance. According to the total manganese content, Ukraine ranks the second position after South Africa, but its quality, due to the high content of harmful impurities (primarily phosphorus oxides), is inferior to the ores of South Africa, Brazil, Australia and Gabon. Most of the manganese stock in Ukraine (80\%) consists of relatively poor carbonate ores with an average content of manganese in $20.7 \%$ [7]. In world practice it is considered that the development of manganese ores 
with a manganese content of at least $35 \%$ is economically viable [8]; otherwise, the cost of ore beneficiation will substantially increase. In other countries supplying this metal, the average content of manganese in ore varies in the range of $40 \ldots 45 \%$, while in Ukraine, the average metal content for all balance stocks is only $23.9 \%$, which is due to the current level of impregnation on this metal, reduces the economic attractiveness of the development of deposits with low manganese content. This poses a potential threat to the competitiveness of domestic enterprises for the extraction and processing of manganese ore in the face of the exhaustion of rich oxide ores, which is intensified in the light of the largescale environmental problems associated with the violation of essential land areas of, as a rule, agricultural purposes, for the extraction of manganese in open manner.

Comparison of quality parameters of manganese ore raw materials at foreign and domestic enterprises is given in Table 1.

Due to the low quality of manganese ores developed in Ukraine, in the domestic market, one third of the consumption of manganese raw materials is made up of imported products. In 2014 and 2015, domestic enterprises exported manganese products in volume, respectively, 40.5 and 111.4 thousand tons. The main consumers of domestic products were countries such as Slovakia, the USA, China, the Czech Republic, and Poland. Instead, import during this period totaled 971.4 thousand tons and 1271.6 thousand tons, indicating an increase in pressure on the domestic market from foreign suppliers of manganese raw materials, in particular from China, Ghana, South Africa, Australia, Russia and Brazil. Today, the world largest manganese market is the following countries (regions): South Africa (26\% of world production), China (26.2\%) Australia (13.7\%) [9]. Particularly impressive is the increase in share of the manganese market in China, which has nearly doubled the supply of this metal in the last ten years, becoming its largest producer in the world.

Thus, nowadays, domestic producers of manganese raw materials are faced with the task of preserving their own market positions and seeking opportunities for increasing the demand for their products, first of all, by applying price competition methods, against the background of objectively lower quality of manganese prod-

Table 1

Comparative assessment of the quality of manganese ore based on the metal content [7]

\begin{tabular}{|c|c|c|}
\hline Parameter of ore quality & 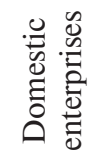 & 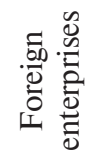 \\
\hline $\begin{array}{l}\text { The average content of metal in all the } \\
\text { balance reserves of manganese, } \%\end{array}$ & 23.9 & $40-45$ \\
\hline $\begin{array}{l}\text { Metal content in concentrates of oxide } \\
\text { ores, } \%\end{array}$ & $37-45$ & $48-50$ \\
\hline $\begin{array}{l}\text { Metal content in concentrates of } \\
\text { carbonate ores, } \%\end{array}$ & $29-31$ & $48-50$ \\
\hline
\end{tabular}

ucts in comparison with products from other supplier countries. Therefore, the orientation of domestic manganese extraction for the supply of concentrate both on the domestic and foreign markets requires the search for ways to reduce the costs associated with obtaining this mineral raw material including costs of reimbursement of negative environmental impacts of mining activities. Due to the technological feature of obtaining mineral raw materials, the main form of organization of production in the mining industry is a combine, an enterprise that combines complexes for mining and processing (beneficiation) of minerals in its composition. Consequently, the plant is an enterprise engaged in production and marketing activities. The effectiveness of the processes associated with the marketing of products, directly depends on the efficiency of the plant to manufacture these products. In general, the managerial decision to increase the competitiveness of the enterprise products should take into account the alternative methods of this result achieving and the reaction of consumers to possible changes in consumer characteristics of products. Thus, management of sales activities of the enterprise involves the coordination of its target plants with regard to the effectiveness of the organization of product turnover and the level of consumer satisfaction with the price and quality characteristics of these products. Target units of sales activities include increase in sales volumes, development of new markets, construction of long-term relations with consumers, reduction of sales costs, and others. Variation of goals will be determined by the state of demand and supply in the market, as well as the level of competitiveness of the products of a particular manufacturer. Objectives of production activity can consist in increasing production volumes, reducing production costs, reducing resource of losses in the production process, limiting negative impacts on the environment, expanding the range of products, and others.

Thus, in the context of the Pokrovsky ODC, the transformation of the production system obviously must be made in the direction of cheapening the processes of preparation and extraction of minerals, for which from the set of variables of the production system it is necessary to choose the variant that will provide the best correlation of qualitative and cost characteristics of the created product. Reducing the cost of manganese extraction would allow spending more money on the formation of manganese concentrate quality within its affordable price range, competitive in foreign markets. Accordingly, today it is important to improve the organizational principles of the introduction of technologies for the development of manganese ore deposits for domestic mining enterprises, aimed at a more complete removal of minerals from minerals and reduction of external expenditures associated with the development of mining works. Currently, the competitiveness of commodity producers in foreign markets is increasingly dependent on whether they comply with the requirements of environmental legislation and are responsible for preserving the natural resource potential of the territories in which their production capacity is located. Industrial reserves of manganese ores in Ukraine are concentrated in the Nikopol 
manganese ore basin where their development is carried out by two enterprises, respectively open and underground - PJSC "Pokrovsky ore mining and processing plant" and PJSC "Marganets mining and concentrating plant". Also developed technogenic deposit "Slurry storage named after Maksymov" (Landscape LLC) [10].

Near the Nikopol basin deposits of manganese are concentrated in Veliko-Tokmatsky, Fedorovske deposits and in the Slurry storage named after Maksymov. There are also deposits of manganese in Ukraine, which are concentrated in the Pobuzko, Donetsk and Carpathian basins, but now these areas are not exploited. Thus, domestic producers of manganese are represented by three mining enterprises, the volume of raw ore extraction on which is shown in Table 2.

The above mentioned mining and concentrating combines produce manganese concentrate and agglomerate, the main consumers of which are ferroalloy enterprises. At present, $90 \ldots 95 \%$ of manganese produced is used in steel production [12]. For the conclusion of contracts for the supply of manganese raw materials, potential consumers will pay attention, first of all, to the following factors that will determine the success of positioning these products on the market: a) quality of raw materials; b) production costs and market price per unit of output; c) the level of social responsibility of the mining enterprises for the consequences of the development, occurrence of conflicts with representatives of other public interests, including the use and degradation of the quality of natural resources.

Currently, the greatest opportunity to reduce the cost of manganese ore extraction is to apply such tech- nologies for the development of the field, which would allow for more complete extraction of mineral raw materials from the entrails. In this case, cost savings would be achieved, primarily, at the expense of the distribution of fixed costs in the cost of production to a larger amount of mining of mineral raw materials. According to [5], the loss of manganese ore in the entrails for its production at domestic enterprises reaches $10 \ldots 10.5 \%$. Instead, due to the reconstruction of mining works, namely by increasing the width of the extraction step (the working space within which the movement of mining equipment is carried out for conducting overburden and mining works) and the slope of the remainder of the ore raw material (the part of the mineral that remains in the deposit) it is possible to achieve a percentage of these losses to the level less than $5 \%$. Table 3 presents variants of technological solutions for changing the named career parameters at PJSC "Pokrovsky ore mining and processing plant", from which it is clear that losses of ore raw materials are significantly reduced with increasing width extraction step and slope angle of the remaining whole ore raw material: in the range of variables under consideration, from 65.9 to 13.06 thousand tons (from 10.18 to $2.01 \%$ ). Thus, changing the parameters of the technological scheme of mining operations, it is possible to significantly affect the level of losses of ore raw materials: in this case, the coefficient of extraction of reserves of the ore layer varies from 0.89 to 0.97 . It is expanding the extraction step to $30 \mathrm{~m}$ and reaching its slope angle of $60 \mathrm{deg}$. allows reducing relative losses of ore raw materials to $2 \%$, which corresponds to 13.1 thousand tons of ore.

Table 2

Production volumes of manganese ore in Ukraine [10, 11]

\begin{tabular}{|l|c|c|c|c|}
\hline \multirow{2}{*}{ Enterprise } & \multicolumn{3}{c|}{ The volume of extraction, thousand t/year } \\
\cline { 2 - 5 } & 2013 & 2014 & 2015 & 2016 \\
\hline PJSC "Pokrovsky ore mining and processing plant" & 2237.0 & 2268.7 & 2339.0 & 1608.1 \\
\hline PJSC "Marganets mining and concentrating plant" & 1204.0 & 1176.2 & 1335.9 & 1186.96 \\
\hline Landscape LLC & 158.5 & 9.45 & - & 79 \\
\hline
\end{tabular}

Table 3

Quantitative estimation of losses of ore raw materials by technology of mining works at manganese quarries [13, 14]

\begin{tabular}{|c|c|c|c|c|c|c|}
\hline \multirow[b]{2}{*}{$\begin{array}{l}\text { Width } \\
\text { extraction } \\
\text { step, m }\end{array}$} & \multirow{2}{*}{$\begin{array}{l}\text { Angle slope } \\
\text { of residual of } \\
\text { whole ore raw } \\
\text { material, degree }\end{array}$} & \multicolumn{2}{|c|}{ Loss of ore reserves } & \multirow{2}{*}{$\begin{array}{l}\text { Area of violation } \\
\text { of land for } \\
\text { compensation of osses } \\
\text { of minerals, hectare }\end{array}$} & \multirow{2}{*}{$\begin{array}{l}\text { Saving of funds } \\
\text { for land } \\
\text { reclamation from } \\
\text { one step, HRN* }\end{array}$} & \multirow[b]{2}{*}{$\begin{array}{l}\text { Preservation } \\
\text { the cost of } \\
\text { land, HRN }\end{array}$} \\
\hline & & $\begin{array}{c}\text { for one } \\
\text { overlapping works, } \\
\text { thousand, } \mathrm{t}\end{array}$ & $\begin{array}{c}\text { relative loss } \\
\text { of mineral } \\
\text { resources, \% }\end{array}$ & & & \\
\hline \multirow[t]{3}{*}{20} & 50 & 65.9 & 10.2 & 1.22 & - & - \\
\hline & 55 & 42.7 & 6.6 & 0.79 & 18017 & 16533.5 \\
\hline & 60 & 19.6 & 3.1 & 0.36 & 36034 & 33067 \\
\hline \multirow[t]{3}{*}{30} & 50 & 43.9 & 6.8 & 0.81 & 17179 & 15764.5 \\
\hline & 55 & 28.5 & 4.4 & 0.53 & 28911 & 26530.5 \\
\hline & 60 & 13.1 & 2.0 & 0.24 & 41062 & 37681 \\
\hline
\end{tabular}

${ }^{*}$ in the area of the PJSC "PGOK” location, agricultural land is located used under arable land 
At the current pace of the front of the mining operations, the company carries out about 3 events annually (one step is equal to 10 hectares). Thus, taking into account the amount of ore raw materials that will be extracted from the subsoil after the proposed reconstruction of the quarries, for preserving the previous volumes of production, it will be enough for the enterprise to carry out not 3 , but only about 2.5 extraction activities during the year, which eliminates the need to violate the land areas corresponding to the area of half of the extraction step. In order to determine the amount of money saving for land reclamation from one step, it is necessary to proceed from the fact that the smaller the percentage of mineral deposits in the depths of the chosen system of development is, the less it is necessary to further disturb the areas of land to compensate for these losses in the planned production of manganese ore products. Therefore, in order to calculate the cost savings for land reclamation for each variant of the technological reconstruction of the quarry (Table 3), it is necessary to determine the difference between the additional need for disturbing the land area for this option and the base version (selected for comparison), the resulting value to be multiplied by cost of reproduction of 1 hectare of land in a certain direction of management.

As the basic variant of the system of development, an option is adopted that determines the highest level of mineral resources losses in the subsoil. Therefore, the following expression should be used to determine the following indicator

$$
E_{r e k_{i}}=\left(Q_{b}-Q_{i}\right) \cdot B_{r . h a},
$$

where $E_{r e k_{i}}$ is cost saving for land reclamation from one extraction step for the ith version of the reconstruction of the quarry, grn.; $Q_{b}, Q_{i}$ are respectively, the area of additional violation of land in the base and ith version of losses of minerals from one extraction step; $B_{r . h a}$ stands for expenses for the reclamation of 1 hectare of disturbed land in the chosen direction of their use.

The value of maintaining the cost of land from reducing the losses of minerals from one extraction step should be determined as follows

$$
E_{l, r_{i}}=\left(Q_{b}-Q_{i}\right) \cdot B_{l . n d},
$$

where $E_{l . r_{i}}$ is the value of the saved value of land with one extraction step on the $i$-th option of career reconstruction; $B_{\text {l.nd }}$ is the cost of one hectare of undisturbed land.

Schematically, the economic effects of the implementation of technological solutions for a more complete removal of ore raw materials based on the reconstruction of quarries are shown in Fig. 1.

Consequently, in contrast to the existing technological schemes for the development of mining operations, it is possible to bring the index of mineral losses to less than $5 \%$, which, accordingly, will affect the total costs of enterprises associated with the development of the deposit, in particular, the costs that must be made for the sake of reproduction of disturbed lands and compensation of deterioration of their quality status. In addition, the company will receive an extra amount of products at constant flat-rate costs, which will also positively affect the total cost of its products. In order to make a decision on the implementation of this or that

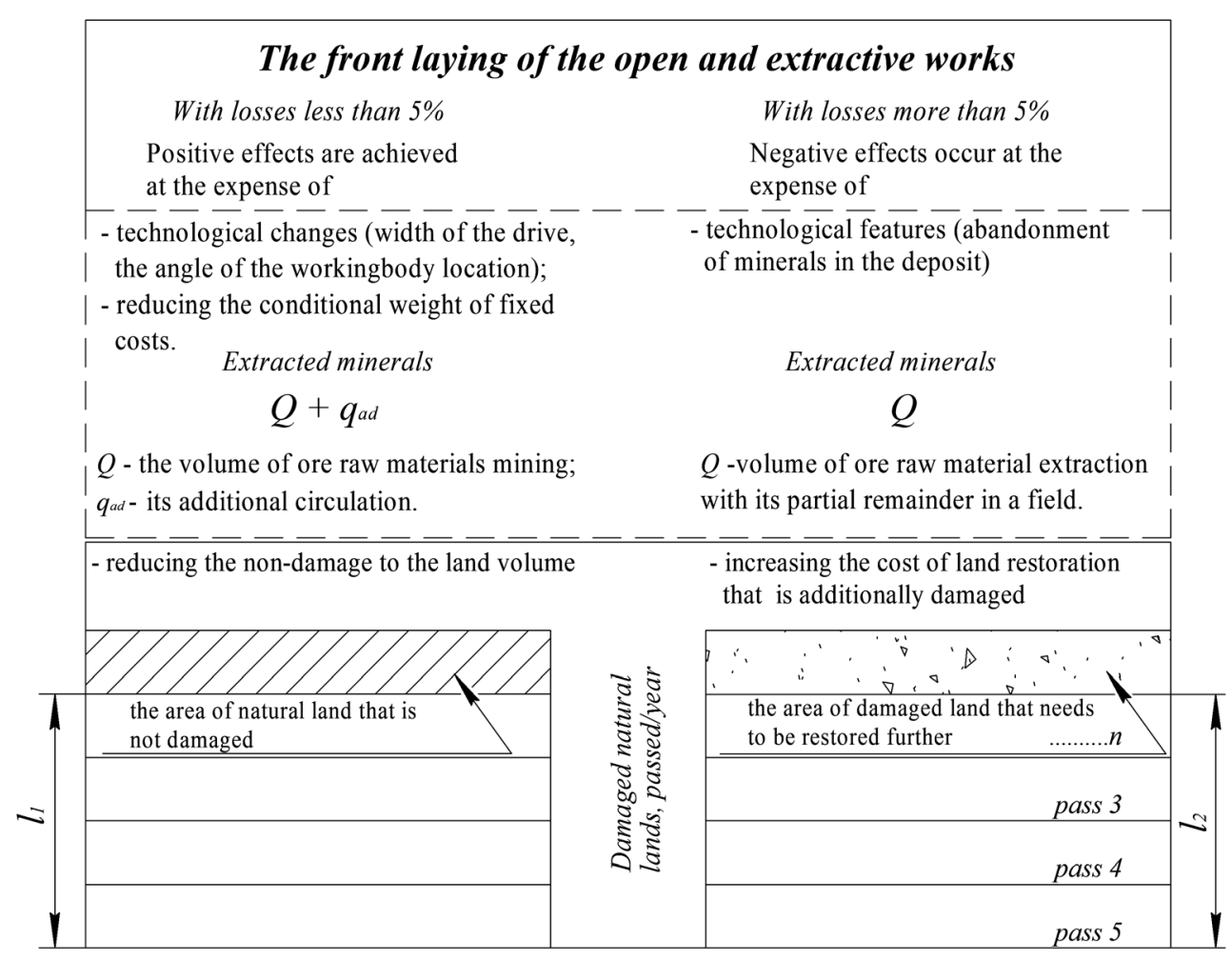

Fig. 1. Ecological and economic effects of reconstruction of the technological scheme while conducting mining operations 
technological development option, first of all, account must be taken of the overall effects that make it possible to increase the competitiveness of the mining company products. In general, reducing the value of technological cost of manganese ore raw materials will create opportunities for reducing the price of its marketing in the market, obtaining additional funds for the implementation of environmental programs of the extractive enterprise. The mining company is not interested in reducing the volume of mining, as it leads to an increase in the cost of a unit of its volume, which in turn reduces the size of the company's profits. In practice, an increase in manganese ore extraction in open mining conditions without additional investment is possible either by accelerating the collapse of mining operations, and, accordingly, implementing a greater number of closures during the year, or through more complete removal of minerals to minimize its losses in the entrails. The first option, as already noted, causes significant losses of mineral resources in the subsoil and involves a larger number of land plots to meet the production program of the enterprise. On the other hand, technological schemes for the extraction of manganese ore, the effectiveness of which is based on the more complete removal of minerals, allows obtaining the following economic effects, which have positive consequences for both the extractive enterprise and other economic entities interested in limiting the mining impacts on the natural environment: 1. Savings of funds for implementation of overlapping works for the purpose of access to deposits of minerals. 2. The increase in the cost of manganese ore due to its less impoverishment through mixing with empty rocks. 3. Getting additional commodity products. 4. Reduction in the cost of a unit volume of manganese ore by reducing the proportion of conditionally fixed costs in its technological cost. 5. Avoidance of expenses for reproduction of those lands that will not be violated during the year. 6. Preservation of the value of lands that have not been violated by mining works. 7. Reducing the costs associated with additional land alienation for open mining.

Thus, those technological schemes for the development of the deposit, envisaging the reconstruction of mining development for the purpose of more complete removal of minerals, can eventually reduce the technological cost of a unit of minerals and, accordingly, increase the amount of profit received from the sale of the total volume of minerals due to the scale effect. From the ecological point of view, such decisions will reduce the integral level of violation of land in the mining industry [15]. The economic content of increasing the competitiveness of manganese ore raw materials on the basis of more rational exploitation of the mineral deposit is given in Fig. 2.

Curve in Fig. 2 shows the change in the magnitude of the profit from the sale of manganese ore products. On the segment $A-B$, the profit profile is represented by the loss of the enterprise for the volume of extraction of minerals, insufficient to cover conditionally fixed costs. Point $B$ describes a break-even amount of production in accordance with the capital costs incurred for the dis-

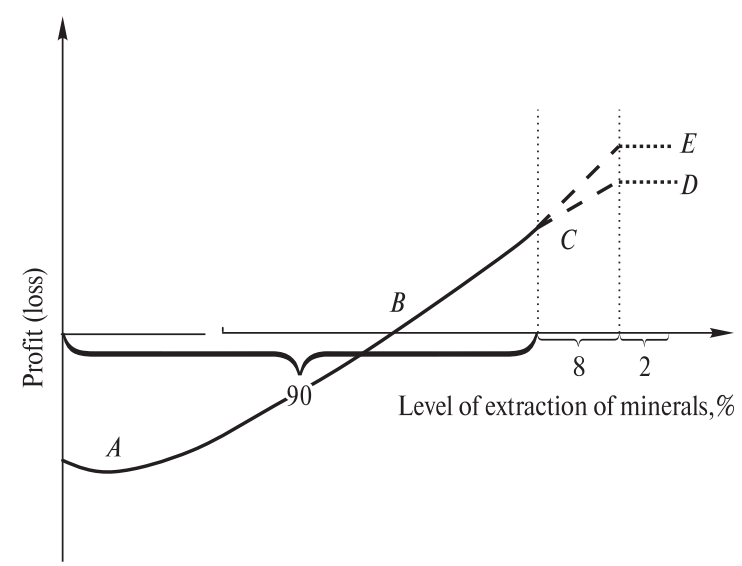

Fig. 2. Dependence of profit from the sale of manganese ore products on the level of extracting minerals from the depths

closure of deposits and their extraction within the limits of a separate extraction step. The formation of profits of the enterprise from the sale of products is on the segment $B-C$, provided that the level of pricing for ore products, in addition to covering costs in the cost, to set the rate of return.

The greater the extraction of minerals per unit of the cost of capital expenditures is, the more rapidly the total profit from its sales will grow. Under the condition of insufficient extraction of ore from the depths (at a loss level of more than $5 \%$ ) it is assumed that the total profit will correspond to point $C$ in Fig. 2 . And only provided the most complete extraction of the useful component from the subsoil (up to $98 \%$ ), the total profit will reach point $D$ due to the saving of funds for the restoration of the area of land that was not violated, as well as compensation for deterioration of its quality, and point $E-$ in addition to level $D$, at the expense of realization of the withdrawn amount of useful minerals falling under the category of losses, for fixed costs of mining operations.

From the analytical point of view, possible decrease in the cost of manganese ore products, which is achieved through the reconstruction of a career on the criterion of ecological and economic efficiency of extractive activities, can be determined by the expression

$$
\Delta S_{c}=\frac{C_{f i x}}{Q_{1}}-\frac{C_{f i x}}{Q_{2}}+\frac{E_{r e k \cdot y}}{Q_{2} \cdot n}+\frac{E_{c o m \cdot p}}{Q_{2} \cdot n},
$$

where $\Delta S_{c}$ is possible reduction in the technological cost per unit of manganese raw material due to the implementation of ecological and economic management of production and sales activities of the enterprise; $C_{f i x}$ is fixed costs for mining on the area of extraction; $Q_{1}, Q_{2}$ are, respectively, the amount of mining of minerals before and after the reconstruction of the quarry on the area of extraction; $E_{\text {rek. } y}$ is annual saving of funds for land reclamation due to reduction of the area of their violations during the year in their careers after reconstruction; $E_{\text {com.p }}$ is annual saving of funds to compensate for the deterioration of land quality due to reduced areas of land subject to violation; $n$ is the number of ex- 
traction quenches that take place in a career during the year.

Thus, the reduction of the component of external costs of the mining enterprise, which is carried out to compensate for the negative environmental consequences of mining development as part of the technological cost of its products, as well as the reduction in constant costs per unit volume of ore raw materials due to more complete extraction of minerals on the area of extraction, is by forming the cost of products supplied to the market, more attractive to potential consumers. On the basis of this, one should expect an increase in sales volumes of domestic producers of manganese raw materials, which, in turn, will allow planning measures for the preservation of the environment in the zone of influence of mining more reasonably. Therefore, the orientation of the production and sales activity of the enterprise to achieve the environmental goals of the development of the deposit is a promising direction of ensuring the competitiveness of its products and improving the efficiency of economic processes in general.

Conclusions and recommendations for further research. The conducted research made it possible to draw the following conclusions:

1. The market for manganese ore products today is characterized by growing demand, and at the same time, increased competition among supplier countries, which poses a threat to domestic manganese producers both in the domestic and foreign markets. Taking into account the differences in the quality of manganese ore of domestic and foreign production, the most effective means of increasing the competitiveness of manganese ore products of domestic enterprises is to reduce the technological cost of its extraction, which will create the attractiveness of its consumption in the corresponding price segment. Instead, the increased cost of ore enrichment will lead to an even greater increase in the cost price of concentrate and disparity between the expected utility and the cost of manganese ore consumption.

2. It was established that in the development of manganese ore deposits, the increase in the competitiveness of domestic mining enterprises should be achieved, first of all, by orienting their production and marketing activities to solve the environmental problems of the development of the deposit, which will positively affect the cost of their products and the possibility of forming its proposal, which will be covered by solvent demand. In this aspect, it is determined that today, in order to reduce the technological cost of manganese ore raw materials, it is necessary to introduce schemes for the development of the deposit, which allow for a more complete extraction of minerals from the entrails and, on the basis of this, reduction in the rate of violation of land in the mining area.

The prospects for further research in this area are the substantiation of the organizational and technological principles of adaptation of the supply of mining products to the market demand for it on the market, determining the appropriate expense for the implementation of environmental programs of the mine-extraction company.

\section{References.}

1. Pyvnjak, G. G., Vagonova, O.G. and Prokopenko, V. I., 2017. Scientific approaches to the development of economic relations between landowners and mining companies. In: Trans Tech Publications, Switzerland. pp. $1-12$.

2. Mormul, T. M. and Terekhov, Ye. V., 2017. Environmental and economic estimation of technological solutions in terms of land resource conservation in the process of open-cast mining. Naukovyi Visnyk Natsionalnoho Hirnychoho Universytetu, 3, pp. 122-128.

3. Sobko, B. Yu., Lozhnikov, O. V., Haidin, A. M. and Laznikov, O. M., 2016. Substantiation of rational mining method at the motronivskyi titanium-zirconium ore deposit exploration. Naukovyi Visnyk Natsionalnoho Hirnychoho Universytetu, 6, pp. 41-48.

4. Jan Per Bethge, Stefan Hörmann, Friedel Hütz-Adams, Sascha Liese and Ann-Kathrin Voge, 2014. Nachhaltige Rohstoffe für den deutschen Automobilsektor. Herausforderungen und Lösungswege. Herausgeber: SÜDWIND e.V. Siegburg.

5. Matyukha, V. V. and Sukhina, O. M., 2016. On the issue of the prospect of sustainable development of the domestic sphere of subsoil use. Economy of industry, 1(73), pp. 43-52.

6. Xiao-chuan Xua, Xiao-wei Gua, Qing Wanga, Xianwen Gaob, Jian-ping Liuc, Zong-kang Wanga and Xunhong Wanga, 2018. Production scheduling optimization considering ecological costs for open pit metal mines. Elsevier. Journal of Cleaner Production [e-journal], 180, pp. 210-221. DOI:10.1016/j.jclepro.2018.01.135.

7. Antakov, Ye., 2013. The current state of world and ukrainian market of manganese: major problems and trends. Bulletin of the Taras Shevchenko National University of Kyiv, Geology, 2(61), pp. 44-48.

8. Mangan und Chrom [online]. Available at: <http:// www.gesichter-afrikas.de/rohstoffe-ressourcen-in-afri$\mathrm{ka} / \mathrm{metallische-rohstoffe/mangan.html}>$ [Accessed 2 August 2017].

9. Rohstoff Mangan - Reichtum vom Grund der Weltmeere [online]. Available at: <https://www.technikeinkauf.de/ratgeber/rohstoffe/rohstoff-mangan-reichtum-vom-grund-der-weltmeere/ $>$ [Accessed 2 August 2017].

10. Ukrnafta, 2017. Extractive Industries Transparency Initiative. National Account of EITI. Ukraine. Kyiv: TOV "Ernst end Yanh".

11. Prymushko, S.I., Biloshapska, T.D. and Velychko, V. F., 2017. Mineral Resources of Ukraine. Kyiv: Derzhavne naukovo-vyrobnyche pidpryyemstvo "Derzhavnyy informatsiynyy heolohichnyy fond Ukrayiny". 12. Ingrid Heinritzi. Rohstoffe-Mangan Mangan - ein besonderer Rohstoff. Wallstreet: Online [online]. Available at: <https://www.wallstreet-online.de/nachricht/ 7984143-rohstoffe-mangan-mangan-besonderer-rohstoff> [Accessed 17 September 2017].

13. Galagan, T. I., 2014. Mine technical stage re-cultivation of the disturbed lands and its ecological and economical evaluation. Gruntoznavstvo - Soil science [online], 1-2(15), pp. 81-88. Available at: <http://nbuv.gov.ua/ UJRN/grunt_2014_15_1-2_10> [Accessed 9 May 2017]. 
14. State Geocadaster. Official site of the State Service of Ukraine for Geodesy, Cartography and Cadastre. Available at: <http://land.gov.ua/info/informatsiiapro-normatyvnu-hroshovu-otsinku-zemel-naselenykhpunktiv-stanom-na-01-10-2016/> [Accessed 11 June 2017].

15. Pavlychenko, A. and Kovalenko, A., 2013. The investigation of rock dumps influence to the levels of heavy metals contamination of soil. In: Mining of Mineral Deposits. Leiden: CRC Press, Balkema, pp. 237-238. DOI: 10.1201/b16354-44/.

\section{Еколого-орієнтоване управління виробничо- збутовою діяльністю підприємства- постачальника марганщеворудної сировини}

\section{Є. В. Терехов, Ю. І. Літвінов}

Державний вищий навчальний заклад „Національний гірничий університет“, м. Дніпро, Україна, e-mail: terehoff@t-online.de

Мета. Теоретичне обгрунтування засад і розробка рекомендацій щодо формування конкурентоспроможності марганцеворудної продукції вітчизняних гірничодобувних підприємств на основі застосування еколого-орієнтованого підходу до управління їх виробничо-збутовою діяльністю. Обгрунтування методичного підходу до оцінки впливу рівня реалізації природоохоронних програм гірничодобувного підприємства на формування технологічної собівартості його продукції, що $є$ основою її успішного просування на ринку.

Методика. У процесі дослідження використані: метод теоретичного узагальнення й систематизації (для визначення особливостей формування конкурентоспроможності вітчизняних виробників марганцеворудної сировини, зображення основних тенденцій розвитку ринку марганцю, визначення напрямів реалізації еколого-орієнтованого управління виробничо-збутової діяльністю гірничодобувного підприємства); статистичний (для відображення показників, що характеризують виробничу діяльність підприємств із видобутку марганцевої руди); аналітичний (для визначення факторів, що впливають на конкурентоспроможність марганцеворудної сировини вітчизняного виробництва).

Результати. На підставі проведеного дослідження запропоновано методичний підхід до формування конкурентоспроможності продукції гірничодобувного підприємства на основі впровадження еколого-орієнтованого управління його виробничозбутовою діяльністю, що враховує наслідки для навколишнього природного середовища від розробки родовища й витрати, пов'язані з ними, у визначенні обсягів збуту та складових ціноутворення марганцеворудної продукції.

Наукова новизна. Запропоновано методичний підхід до формування конкурентоспроможності продукції гірничодобувного підприємства на основі впровадження еколого-орієнтованої системи управління його виробничо-збутовою діяльністю, що передбачає суттєвий вплив рівня реалізації природоохоронних програм підприємства та заходів щодо більш раціональної розробки родовища на зниження технологічної собівартості продукції як ключового чинника формування попиту на марганцеворудну сировину на внутрішньому й зовнішньому ринках.

Практична значимість. Отримані результати спрямовані на вдосконалення методичних основ управління конкурентоспроможністю продукції гірничодобувного підприємства з використанням цінових методів іiї формування. Урахування впливу екологічних чинників освоєння родовища на конкурентоспроможність марганцеворудної сировини дозволить цілеспрямовано визначати іiі вартісні характеристики, сприятливі для активізації іï попиту на ринку.

Ключові слова: марганцеворудна сировина, еколого-орієнтоване управління, собівартість продукції, конкурентоспроможність, землезбереження, раціональне освоєння надр

\section{Эколого-ориентированное управление производственно-сбытовой деятельностью предприятия-поставщика марганцеворудного сырья}

\section{Е. В. Терехов, Ю. И. Литвинов}

Государственное высшее учебное заведение „Национальный горный университет“, г. Днепр, Украина, e-mail: terehoff@t-online.de

Цель. Теоретическое обоснование принципов и разработка рекомендаций по формированию конкурентоспособности марганцеворудной продукции отечественных горнодобывающих предприятий на основе применения эколого-ориентированного подхода к управлению их производственносбытовой деятельностью. Обоснование методического подхода к оценке влияния уровня реализации природоохранных программ горнодобывающего предприятия на формирование технологической себестоимости его продукции, что является основой ее успешного продвижения на рынке.

Методика. В процессе исследования использованы: метод теоретического обобщения и систематизации (для определения особенностей формирования конкурентоспособности отечественных производителей марганцеворудного сырья, изображения основных тенденций развития рынка марганца, определения направлений реализации экологоориентированного управления производственносбытовой деятельностью горнодобывающего предприятия), статистический (для отображения показателей, характеризующих производственную деятельность предприятий по добыче марганцевой руды), аналитический (для определения факторов, влияющих на конкурентоспособность марганцеворудного сырья отечественного производства). 
Результаты. На основании проведенного исследования предложен методический подход к формированию конкурентоспособности продукции горнодобывающего предприятия на основе внедрения эколого-ориентированного управления его производственно-сбытовой деятельностью, учитывает последствия для окружающей среды от разработки месторождения и расходы, связанные с ними, в определении объемов сбыта и составляющих ценообразования марганцеворудной продукции.

Научная новизна. Предложен методический подход к формированию конкурентоспособности продукции горнодобывающего предприятия на основе внедрения эколого-ориентированной системы управления его производственно-сбытовой деятельностью, что предполагает существенное влияние уровня реализации природоохранных программ предприятия и мероприятий по более рациональной разработке месторождения на снижение технологической себестоимости продукции как ключевого фактора формирования спроса на марганцеворудное сырье на внутреннем и внешнем рынках.

Практическая значимость. Полученные результаты направлены на совершенствование методических основ управления конкурентоспособностью продукции горнодобывающего предприятия с использованием ценовых методов ее формирования. Учет влияния экологических факторов освоения месторождения на конкурентоспособность марганцеворудного сырья позволит целенаправленно определять ее стоимостные характеристики, благоприятные для активизации ее спроса на рынке.

Ключевые слова: марганцеворудное сырье, эколого-ориентированное управление, себестоимость продукции, конкурентоспособность, землесбережение, рациональное освоение недр

Рекомендовано до публікації докт. екон. наук Ю.І.Пилипенком. Дата надходження рукопису 19.05.17. 